\title{
Experimental Research on SOx from Ship Emissions by Lye Absorption
}

\author{
Wang Zhongcheng ${ }^{1}$, Zhou Peilin ${ }^{2}, \mathrm{Xu}_{\text {Lepin }}{ }^{1}$ and Jiang Minming ${ }^{1}$ \\ 1. MMC of Shanghai Maritime University, Shanghai 201306, China \\ 2. Strathclyde University, UK
}

\begin{abstract}
To protect environment, and to comply with the IMO's (International Maritime Organization) newest regulations about ship's SOx emission. This thesis illustrates a closed recycling absorb system based on $\mathrm{NaOH}$ solution recycling particularly for SOx onboard. The goal is to use $\mathrm{NaOH}$ solution to absorb SOx, and reduce the damage the ships made towards environment. The thesis analyzes the main features that could influence the absorption of SOx on board, and the precipitations during the experiment. To reveal that $\mathrm{NaOH}$ solution is very highly effective and economic in absorption of SOx on ships by this experiment, and to set a theoretical basic fundamental for future application of alkali solution recycling absorption system for SOx.
\end{abstract}

Key words: Environment protection, marine diesel engine, emission control, $\mathrm{SO}_{\mathrm{x}}$, economy.

\section{Introduction}

The main content of SOx emission onboard is $\mathrm{SO}_{2}$, it is the main pollution gas of atmosphere. $\mathrm{SO}_{2}$ [1] can stipulate mucous in aspiration system, it will make people breath less air and cause coughing when reaching certain concentration. It also can cause dyspnea, chest distress, even death if the concentration continues rising. $\mathrm{SO}_{2}$ [2] can form acid rain and photochemical smog, cause damage to creatures and plants alike.

Diesel engines on ship use fuel which contents 3\% of sulfur, the $\mathrm{SO}_{2}$ proportion is low in exhaust gas. But due to vast amount of ships and long distance traveling, the fuel consumption is huge, thus the $\mathrm{SO}_{2}$ emission of ships [3] is huge. According to a survey submitted to IMO by Norway, the distribution of SOx by ships has reached $7 \%$ of the world's SOx emission [4]. The SOx emission from diesel engines on ships severely pollutes atmosphere, it even becomes the major pollution source in some ports and heavy traffic zones.

The fifty-eighth session of Marine Environment

Corresponding Author: WANG Zhongcheng, Ph.D., lecturer, research field: ship power plant technology management.
Protection Committee held 6 to 10 October 2008 (MEPC 58/23) had approved the amendment for further restriction of ship's emission. The amendment came into force at 1st July 2010. The allowable amount of fuel sulfur was reduced to $1.0 \%$ in July 2010 and is to be further lowered to $0.1 \%$ in January 2015 in ECA (Emission Control Area), or else the shipping company would implement emission trading with same amount [5]. Outside of ECA's, the current global limit of 4.5\% sulfur-in-fuel will be reduced to $3.5 \%$ in 2012, then $0.5 \%$ in 2020 or 2025 depending on a review in 2018 to determine the availability of fuel to enable implementation of this standard. US and EU [6] have regulated the fuel sulfur for ships cannot exceed $0.1 \%$ for all the ship's to dock in its area. Thus the emission of SOx is facing huge pressure, it is necessary to reduce SOx on board.

\section{Current Condition}

There are pre-processing and post-processing to desulfurize ship's emission: pre-processing is low the concentration of the sulfur in fuel before it enters engine, post-procession is process the SOx in exhaust gas. But pre-process involves fuel distillation 
technology which is complicated and costly. Besides, a series problem will occur if engine runs in low sulfur fuel. Thus pre-process is not widely adopted.

Most research facilities are focusing on post-process for emission desulfurization. The research progress for ship's SOx emission reduction world widely is still in test. Wartsila, Alfa Laval Aalborg, Belco, Clean Marine, Couple, MAN, MESare doing R\&D for this field. The research on this field in china is rather rarer, mainly Dalian Maritime University [7], Wuhan Textile University [8], and Shanghai Maritime University [9] etc. have done it. The emphases of their research are mainly about open desulfurization based on seawater [10, 11]or desulfurization system based on plasma [12] but never closed recycling desulfurization for ships.

This thesis adopts $\mathrm{NaOH}$ solution, with closed recycling system to absorb the $\mathrm{SO}_{2}$ in exhaust gas of ships, analyzes the influence of changing for start temperature, gas inlet rate, $\mathrm{NaOH}$ solution concentration, diameter of the reactor, height of solution, also analyzes the economy for desulfurization with closed recycling alkali system, so as to set a basic theory for future application of alkali solution recycling absorption system for Sox.

\section{Experiment Theory}

The main component for Ship's SOx in the exhaust gas is $\mathrm{SO}_{2}$, so this experiment will use $\mathrm{SO}_{2}$ as research target.

Pump $\mathrm{SO}_{2}$ into a certain concentration solution of $\mathrm{NaOH}$, analyzes the absorption effect under different conditions (concentration of $\mathrm{NaOH}$ solution, $\mathrm{SO}_{2}$ inlet, temperature, diameter and height of the reactor). This experiment content a steel cylinder 4 as the container of $\mathrm{SO}_{2}$; reactor 5 ; relief valve 1 ;pressure gauge 2 ; flow meter 3; high-accuracy electronic balance scale 7; gear pump 8; collector 9 etc. The experiment duration was 30 minutes, record data every 2 minutes, and analyze sample. The experiment equipment is shown in Fig. 1. $\mathrm{SO}_{2}$ stores in steel cylinder, adjusting its outlet pressure by relief valve to 0.11 Mpa which was similar to the pressure [13] of exhaust gas of ship's engine. Then the gas will go through the barometer and a diffuser to Fine bubble before access to $\mathrm{NaOH}$ solution, so the absorb effect would be maximized. There are two gear pumps drive the whole recycle system, the high-accuracy electronic balance would measure the mass change for $\mathrm{SO}_{2}$ and the reactor. Its chemical equation [14] is shown in Eq. (1):

$$
2 \mathrm{NaOH}+\mathrm{SO}_{2}=\mathrm{Na}_{2} \mathrm{SO}_{3}+\mathrm{H}_{2} \mathrm{O}
$$

\section{Experiment Result and Analysis}

\subsection{Influence of Startup Temperature for Absorptivity}

In order to find out the influence of startup temperature for $\mathrm{SO}_{2}$ absorptivity, the experiment adopted $25^{\circ} \mathrm{C}, 40^{\circ} \mathrm{C}$, and $55^{\circ} \mathrm{C}$ as startup temperature. All the following conditions were constant as $\mathrm{SO}_{2}$ inlet flow was $0.5 \mathrm{~L} / \mathrm{min}, \mathrm{NaOH}$ solution concentration was $4 \mathrm{~mol} / \mathrm{L}, \mathrm{NaOH}$ solution height was $240 \mathrm{~mm}$, reactor diameter was $125 \mathrm{~mm}$, diffuser diameter was $104 \mathrm{~mm}$, duration was 30 minutes, record data every 2 minutes and sample than calculate average value. The result is shown in Fig. 2.

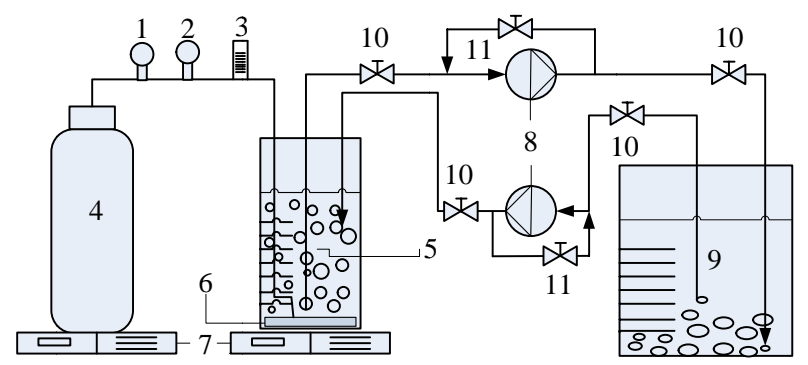

Fig. $1 \mathrm{SO}_{2}$ assimilation equipment.

1-relief valve; 2-pressure gauge(outlet pressure); 3-flowmeter; 4-SO $\mathrm{S}_{2}$ bottle; 5-reactor of $\mathrm{NaOH}$ solution; 6-diffuser; 7-high-accuracy electronic balance scale; 8- gear pump; 9-collector;10-flow control valve;11-bybass valve.



Fig. 2 The influence of startup temperature for $\mathrm{SO}_{2}$ assimilation rate. 
According to Fig. 2, the absorptivity reaches $89.42 \%$ when the startup temperature is $25^{\circ} \mathrm{C}$. As the Startup temperature raised, the absorptivity is decreasing. The absorptivity declined to $81.80 \%$ when the startup temperature raised to $40{ }^{\circ} \mathrm{C}$. The absorptivity reduced to $77.83 \%$ when startup temperature reaches $55{ }^{\circ} \mathrm{C}$. The cause of this is that the reaction between $\mathrm{NaOH}$ and $\mathrm{SO}_{2}$ is a neutralization reaction which generates heat. High temperature is not fit for reaction. Thus it's recommended to minimize the temperature of $\mathrm{NaOH}$ solution in reality application.

\subsection{Influence of Concentration of $\mathrm{NaOH}$ Solution for Absorptivity.}

Prepare $\mathrm{NaOH}$ solution with concentration of 2 $\mathrm{mol} / \mathrm{L}, 4 \mathrm{~mol} / \mathrm{L}, 8 \mathrm{~mol} / \mathrm{L}$, the experiment condition stays constant as temperature was $25^{\circ} \mathrm{C}, \mathrm{SO}_{2}$ inlet flow was $0.5 \mathrm{~L} / \mathrm{min}, \mathrm{NaOH}$ solution heights was $240 \mathrm{~mm}$. The result is shown in Fig.3.

According to Fig. 3, when the concentration of $\mathrm{NaOH}$ solution was $2 \mathrm{~mol} / \mathrm{L}, 4 \mathrm{~mol} / \mathrm{L}$ and $8 \mathrm{~mol} / \mathrm{L}$, the absorptivity reached $88.48 \%$, $89.42 \%$ and $91.51 \%$.It shows that $\mathrm{SO} 2$ absorptivity is proportional to the concentration of $\mathrm{NaOH}$ solution. The absorptivity increased $0.94 \%$ when the concentration of $\mathrm{NaOH}$ solution raised from $2 \mathrm{~mol} / \mathrm{L}$ to $4 \mathrm{~mol} / \mathrm{L}$, and it increased $2.09 \%$ when the concentration of $\mathrm{NaOH}$ solution raised from $4 \mathrm{~mol} / \mathrm{L}$ to $8 \mathrm{~mol} / \mathrm{L}$. the absorptivity of $\mathrm{SO}_{2}$ increases palpably with the rising of $\mathrm{NaOH}$ solution concentration. The higher the concentration of $\mathrm{NaOH}$ solution, the better it absorbs $\mathrm{SO}_{2}$. But actually the absorptivity is already above $90 \%$ when the concentration reaches $6 \mathrm{~mol} / \mathrm{L}$, so economically, it is not recommended to use solution that has higher concentration than $6 \mathrm{~mol} / \mathrm{L}$.

\subsection{The Influence of $\mathrm{SO}_{2}$ Inlet Rate for Absorptivity}

To analyze influence of the $\mathrm{SO}_{2}$ inlet rate for absorptivity, the experiment adopted three inlet rate as $0.5 \mathrm{~L} / \mathrm{min}, 1.0 \mathrm{~L} / \mathrm{min}$ and $1.5 \mathrm{~L} / \mathrm{min}$. The other experiment condition stays constant as temperature was $25{ }^{\circ} \mathrm{C}, \mathrm{NaOH}$ concentration is $8 \mathrm{~mol} / \mathrm{L}, \mathrm{NaOH}$ solution heights was $240 \mathrm{~mm}$. The result is shown in Fig. 4.

According to Fig. 4, the absorptivity raised when $\mathrm{SO}_{2}$ inlet rate increased. The absorptivity was $89.43 \%$ when $\mathrm{SO}_{2}$ inlet rate was $0.5 \mathrm{~L} / \mathrm{min}$, the absorptivity 92.14\% when $\mathrm{SO}_{2}$ inlet rate was $92.14 \%$. The absorptivity was $92.27 \%$ when $\mathrm{SO}_{2}$ inlet rate was 1.5 $\mathrm{L} / \mathrm{min}$. as it shows, the absorptivity increased $2.73 \%$ when the $\mathrm{SO}_{2}$ inlet rate raised from $0.5 \mathrm{~L} / \mathrm{min}$ to 1.0 $\mathrm{L} / \mathrm{min}$. But the absorptivity only increased $0.13 \%$ when $\mathrm{SO}_{2}$ inlet rate raised from $1.0 \mathrm{~L} / \mathrm{min}$ to $1.5 \mathrm{~L} / \mathrm{min}$. so it is recommended that $\mathrm{SO}_{2}$ inlet rate is not very big when applied in practical absorption.

\subsection{The Influence of Reactor Diameter for Absorptivity}

To analyze the influence of reactor diameter for absorptivity, the experiment has adopted reactors with diameters as $120 \mathrm{~mm}, 180 \mathrm{~mm}$ and $240 \mathrm{~mm}$. The other experiment condition stays constant as temperature was $25{ }^{\circ} \mathrm{C}, \mathrm{NaOH}$ concentration is $4 \mathrm{~mol} / \mathrm{L}, \mathrm{NaOH}$ solution height was $240 \mathrm{~mm}, \mathrm{SO}_{2}$ inlet rate $0.5 \mathrm{~L} / \mathrm{min}$, diffuser diameter $104 \mathrm{~mm}$. The result is shown in Fig. 5.

According to Fig. 5, the absorptivity raised at first than fall with the rise of the reactor diameter. The absorptivity increased from $89.42 \%$ to $91.67 \%$ when

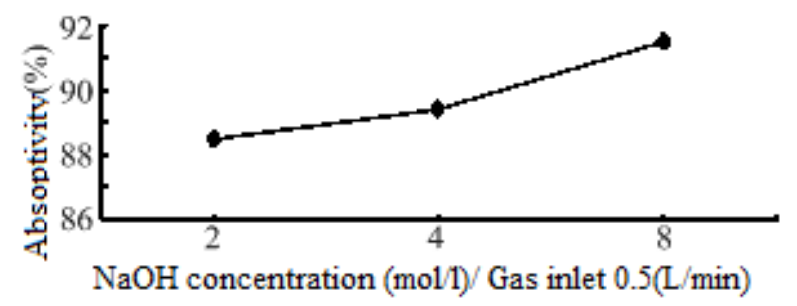

Fig. 3 The influence of $\mathrm{NaOH}$ concentration for $\mathrm{SO}_{2}$ absorptivity.

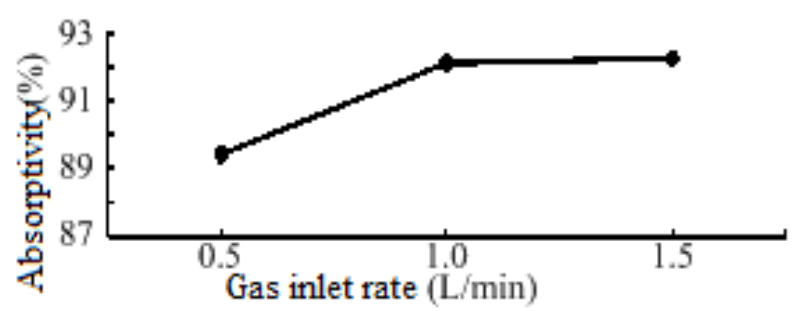

Fig. 4 The influence of $\mathrm{SO}_{2}$ inlet rate for absorptivity. 


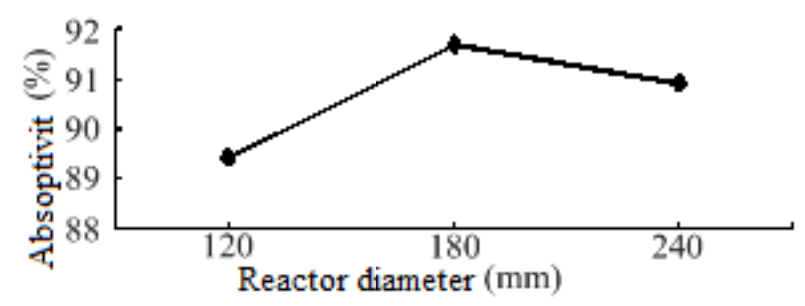

Fig. 5 Influence of reactor diameter for absorptivity.

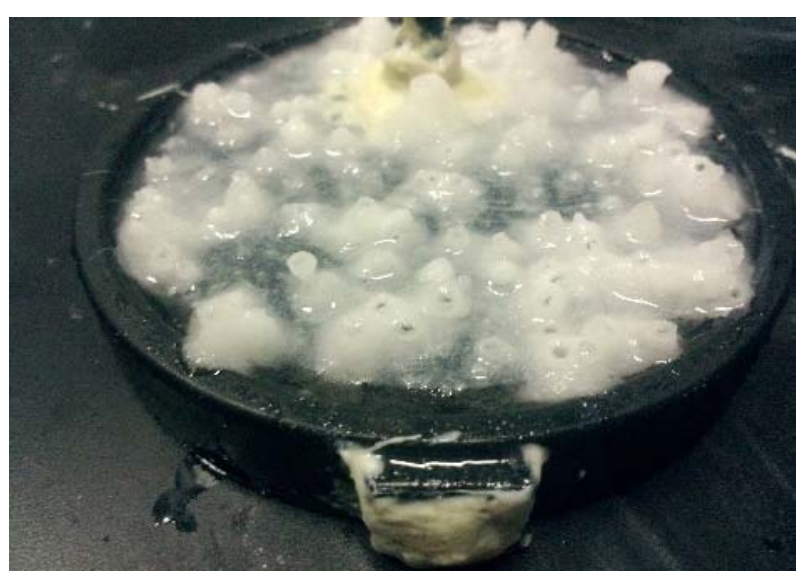

Fig. 6 Sodium sulfite precipitation.

Table1 Cost calculation for recycling alkali solution SOx absorb system.

\begin{tabular}{|l|l|}
\hline Oil consumption $(\mathrm{kg} / \mathrm{h})$ & $0.17 * 8,500=1,445$ \\
\hline $\mathrm{SO}_{2}$ output $(\mathrm{kg} / \mathrm{h})$ & $2.7 \% * 1,445 * 2=78.03$ \\
\hline Necessary $\mathrm{NaOH}$ amount need $(\mathrm{kg} / \mathrm{h})$ & $78.03 * 80 / 64=97.5$ \\
\hline NaOH price $(\$ / \mathrm{T})$ & 256 \\
\hline $\begin{array}{l}\text { Cost of process exhaust gas of } 2.7 \% \\
\mathrm{HFO}(\$ / \mathrm{T})\end{array}$ & $256 * 0.0975 / 1.445=17.3$ \\
\hline $\mathrm{BW} 380$ price $(\$ / \mathrm{T})$ & 337.00 \\
\hline BW0.1\%S $(\$ / \mathrm{T})$ & 600.50 \\
\hline Different of cost per ton $(\$ / \mathrm{T})$ & 263.5 \\
\hline
\end{tabular}

Oil price source: Bunker world.

reactor diameter raised from $120 \mathrm{~mm}$ to $180 \mathrm{~mm}$. As the reactor diameter reaches $240 \mathrm{~mm}$, the absorptivity reduced to $90.91 \%$. The influence of reactor diameter is greater than $\mathrm{NaOH}$ solution height. But the absorptivity maximized when the ratio of reactor diameter over diffuser diameter reaches 1.8.

\subsection{The Analysis of Precipitations during Experiment}

The precipitation progress happened in experiment varies by the $\mathrm{SO}_{2}$ inlet rate. Less precipitations appeared when $\mathrm{SO}_{2}$ inlet rate and $\mathrm{NaOH}$ solution concentration were both low, and vice versa. When
$\mathrm{SO}_{2}$ inlet rate was $1.5 \mathrm{~L} / \mathrm{min}$ and the $\mathrm{NaOH}$ solution is $8 \mathrm{~mol} / \mathrm{L}$, the solution turns white after 10 minutes, then turns turbid later on. There were white precipitations on the diffuser, as is shown in Fig. 6.

This is sodium sulfite according to analysis. The distribution of precipitation is uneven on the diffuser. The cause is that the resultant-sodium sulfite can be dissolved when the experiment begins because it is not abundant in the water. Sodium sulfite begins to precipitate after reaching saturated concentration. Sodium sulfite mainly gathers at the surface of diffuser especially where the $\mathrm{SO}_{2}$ inlet is big by the efforts of tensions between molecules.

\section{Analysis of Economy}

The analysis of economy for ship's closed recycling SOx absorb system with sodium hydroxide solution contains: equipment cost and operation cost.

Equipment cost [15]: The equipment cost is rather expensive. It will need 1-4 years to repay the cost as the price for whole set is 1.5 million.

Operation cost: Set an occasion as a $10 \mathrm{MW}$ unit running with MCR is at $85 \%$ and consumes $2.7 \%$ HFO. The specific fuel consumption rate for this is 170 $\mathrm{g} / \mathrm{kW} \cdot \mathrm{h}$. see Table 1 .

According to Table 1: It needs $17.3 \$ / t$ to process $2.7 \%$ HFO for diesel engines with $10 \mathrm{MW}$ power. While the different of cost between $2.7 \%$ HFO and $0.1 \%$ HFO is 263.5 dollars.

\section{Conclusions}

This thesis studies on ship's SOx absorption with $\mathrm{NaOH}$ solution. The usage of $\mathrm{NaOH}$ solution for $\mathrm{SO}_{2}$ absorption is effective and economical according to experiment. The adoption of closed recycling system prevents the damage to sea environment. The reduction of cost varied by duration the ship's sailing in the emission control area. According to the calculation with the current oil price, 363.46\$ could be saved per hour for a ship with $10 \mathrm{MW}$ power in emission control area, which is rather economical. 


\section{References}

[1] CAO, D. M. 2013. " $\mathrm{SO}_{2}$ Pollution and Its Hazards and Control Technology in China.” Environmental Science Survey 32(2): 73-5.

[2] LI, W. 2013."Research on Sulphur Emissions Control Technology of Marine Diesel.” Wuhan: Wuhan University of Technology.

[3] LI, S. M., DONG, Y. H., ZHANG, C. L., ZHANG, L., and DONG, L. H. 2013. "Development of Domestic and International Marine Exhaust Gas Treatment.” Mechanical Engineer (5): 1-5.

[4] LU, K. J., SONG, Z. C., and DAI, X. L. 2010. "A Study on the Effect of Fuel Sulfur Content on Emission Characteristics of Diesel Engine." Automotive Engineering 32(4): 299-302.

[5] WANG, X. Z. 2010. "The Damage of Ship Diesel Engine Exhaust Gas and Emissions Limits.” Science \& Technology Information (1): 145-6.

[6] ZHANG, T. L., LIU, Q., and GUO, L., et al. 2014. "Regulations Analysis of Sulfur Oxide Emission Control from Ship.”World Shipping (37): 55-7.

[7] HAO, Y. 2011. "Removal Efficiency of Magnesium Base-seawater Desulfurization for Marine Flue Gas.” Dalian: Dalian Maritime University, 2011.

[8] YU, Q., and YU, G. 2010. “A Desulfurization and
Denitration Device for Marine Exhaust Integration.” China: State Intellectual Property Office.

[9] MA, Y. P. 2014. "The Mechanism Research of Seawater Scrubbing for $\mathrm{SO}_{2}$ Removal from Ship's Powerplant Exhaust Gas.” Shanghai: Shanghai Maritime University.

[10] MA, Y. P., XU, L. P., SU, P. H., and YANG, K. L. 2013. "Simulation and Design of Ship Flue Gas Desulphurization Using Seawater." Journal of Shanghai Maritime University 34(2): 42-5.

[11] MA, Y. P., and XU, L. P. 2011. "The Application of Seawater Desulphurization in Controlling Ship's Sulfur Oxides Emission.” Ship Engineering (33): 190-3.

[12] ZHANG, J. B., ZHOU, Y., ZHONG, Z. P., JIANG, X. X., and PIAO, G. L. 2014. "Experimental Study on Simultaneous Desulfurization and Denitrification with Ammonia in WFGD System Combined with Plasma Oxidation of NO.” Journal of Southeast University (44): 1194-8.

[13] FU, K. Y., and Zhou, M. R. Marine Diesel Engine. Shanghai: Shanghai Pujiang Education Press.

[14] DING, Z. W. 2014.Chemical Engineering Principles Study Guide. Beijing: Chemical Industry Press.

[15] ZHOU, S., LI, C., and SHEN, F. X. 2014. "The Status of Marine Engine Exhaust Gas Scrubbing and Desulfurizing Technology and its Development Trend.” Diesel Engine (36): 1-6. 